\title{
Analysis of Technology Management Functions in Finnish High Tech Companies
}

\author{
Hanna Kropsu-Vehkapera*, Harri Haapasalo and Jukka-Pekka Rusanen
}

Department of Industrial Engineering and Management, University of Oulu, Finland

\begin{abstract}
Technology management (TM) for companies is about sustaining and improving a company's competitiveness in the long-term. The aim of this study is to identify the common perception of TM functions in Finnish high tech companies, which elements are the most critical for them, and where the biggest development needs are in practice. The study was realised qualitatively in 15 Finnish high tech companies. Interviews were held with persons responsible for company management activities in the area of technology. The results show many similar characteristics in the case companies, such as the nature of the technology strategy, the mode of co-operation in technology development, or the ways of acquiring technologies. However, differences were also identified mainly in the companies' business models and company size. None of the functions of TM, were evaluated as the most important by the case companies. However, certain functions of TM were highly appreciated and are mostly related to the engineering activities, such as product development, technology development, information and knowledge management, life cycle management, and production process management.
\end{abstract}

Key Words: Technology management, technology management functions, high tech companies.

\section{INTRODUCTION}

The a im of technology management (TM) is to sustain and improve the competitive position of a company's technology exploitation. The management of te chnology should comprise th ree $\mathrm{m}$ ajor factors: leadership, motivation of em ployees and appropriate management of technology [1]. The goal of TM is to create a synergy among all the factors (i.e. research, development, planning, engineering, machines, software, produc tion, and communication) to $\mathrm{m}$ ake them wor $\mathrm{k}$ together in the most ef ficient $\mathrm{w}$ ay to $\mathrm{p}$ roduce $\mathrm{p}$ rofit for the company in the long-term.

Companies are under constant pressure to be innovative, to introduce new products and services to create difference in the market, and to make process innovations to improve their business $\mathrm{p}$ erformance [2]. Rapid $\mathrm{c}$ hanges in the bus iness environment a nd gl obal c ompetition forc es companies to understand the business opportunities and risks of new technologies, a nd how im portant te chnological innovations a re for i ndustrial c ompetitiveness $[3,4]$. T echnological i nnovations $\mathrm{c}$ an i nvolve $\mathrm{c}$ hanges $\mathrm{i} \mathrm{n}$ produc ts a nd s ervices o $\mathrm{r}$ changes in the ways of ope rating (i.e. proc ess innovation) [5]. To create these changes, technology management is an inevitable necessity for companies to survive in global competition and sustain their bus iness. However, there is ongoing discussion in the scientific community about what really is the content of $\mathrm{T} \mathrm{M}$. Also the practitioners in industry are setting $d$ ifferent pra ctices for $m$ anaging technology. $T$ his makes th e s ituation more co mplicated in real management situations.

*Address c orrespondence t o this author at the D epartment of I ndustrial Engineering and Management, University of Oulu, Finland; Tel: +358-445445835; Fax: +358-8-553-2904; E-mail: hanna.kropsu-vehkapera@oulu.fi
Finnish companies have been well known for their technical engineering and product de velopment $r$ elated $\mathrm{c}$ apability, but there are shortcomings in the strategic and business management levels [6]. Thus we decided to c ollect knowledge a bout the c urrent $\mathrm{s}$ tate of $\mathrm{T} \mathrm{M}$ in $\mathrm{F}$ innish companies. Before analysing the practices, we outline the functions of technology management a ccording to the current literature. After that, we ex amine these functions in practice and identify the areas for development and importance of those. This approach is condensed into the following research questions:

RQ1. What are the main functions in Technology Management?

RQ2. How do these functions emerge in some Finnish high technology companies?

The paper is organised as follows: first, the functions of $\mathrm{TM}$ are defined; the methodology section describes how the empirical research was carried out; the empirical results are compiled and presented in relation to the research question; finally, the results are discussed and conclusions are drawn.

\section{FUNCTIONS OF TECHNOLOGY MANAGEMENT}

Technology management (TM) or Management of Technology (MoT) is extensively discussed in recent research and literature. A wi de range of li terature on ne w product development (NP D) $\mathrm{m}$ anagement, R\&D management, $\mathrm{s}$ trategic management, $\mathrm{m}$ anagement of $\mathrm{i}$ nnovation, long-range $\mathrm{pl}$ anning, technological forecasting etc. can be found in the journals and te xt books. Ne vertheless, technology management is a separate fie ld of $\mathrm{m}$ anagement $\mathrm{s}$ cience $\mathrm{s}$ ince the 1970s and early 1980s. The National Research Council (NRC) and U.S. industry orga nised a c ross di sciplinary works hop in 1986 to de fine a theoretical founda tion for M oT [7]. After 
that, a significant amount of lit erature was produced on op erationalising technology management into other approaches in management (see e.g. [8-15]). Dussauge [13], Bhalla [16], Steele [8], and Betz [11] a mong others introduced their generic MoT books from a strategic viewpoint, and defined key considerations and concepts in the MoT area. Steele [8] presented a classification of produc $t$, m anufacturing and information te chnology. Mitchell and $\mathrm{H}$ amilton [17] propos ed a model for $t$ he $s$ trategic pos itioning of R\& $D$ e fforts us ing strategic technological options. Matthews [18] further developed the model to reduce technological uncertainty based on Mitchell's and Ha milton's work. After that Matthews [10] introduced a $\mathrm{h}$ olistic co nceptual $\mathrm{f}$ ramework $\mathrm{f}$ or in tegrating technology into business strategy. Dodgs on [19] a nd Carayannis [20] c ombined te chnology $\mathrm{m}$ anagement, orga nisational, and a learning point of view.

Technology, especially in the strategic context, refers to technological competence or knowl edge rather than explicit technical solutions. Dodgson [12] crystallized, technological competence as simply competence with a technological basis - an ability to compete with technology. Several technology definitions support this conclusion. For example, S teele [8] defines the capability that an en terprise needs. Burgelman et $a l$. [9] re fers to theoretical and pra ctical knowl edge. Dus sauge [13] propos es the application of s cientific knowledge. In conclusion, the key implication is that the aim of technology management is to understand the real difference between competitive a dvantage achieved by te chnological c ompetence and competitive advantage achieved by certain technical solutions. When competence is core or strategic, it gives a sustainable competitive advantage that cannot be copied or imitated b y co mpetitors. F rom a co mpany's $v$ iewpoint, a $n$ essential issue is that only by de veloping technology it self can it learn about, and achieve this kind of profound competence. Another choice is to buy te chnology from an external source, but then an individual c ompany is d ependent upo $n$ the competence, an $\mathrm{d} p$ erhaps loyalty, of co llaborators an $\mathrm{d}$ technology s uppliers. I t could e ven be said that technical solutions can be bought, but technology is impossible to buy. [21].

Overall, T M ove rlaps s everal ot her a pproaches, s chools and pa radigms for $\mathrm{m}$ anaging te chnology a nd $\mathrm{R} \& \mathrm{D}$ i $\mathrm{n}$ the strategic co ntext. However, tw o $m$ ain streams of 1 iterature can be identified in science and engineering (e.g. R\&D management and innovation management), and in economics and management $\mathrm{s}$ cience ( $\mathrm{s}$ trategic $\mathrm{m}$ anagement a nd bus iness administration). $T$ he fie ld of $t$ echnology $m$ anagement ha $s$ also been approached from other management paradigms and areas of science (e.g., organisational theory and quality management). A ccording to $T$ alonen [21] it is $f$ air to $s$ ay th at management of te chnology is more a set of conceptual approaches than an exact paradigm or field of science.

Because of $t$ he interdisciplinary e volvement and the nature of technology management, and lack of commensurable frameworks, there are several typologies and approaches for defining functions in technology management. These different vie ws of TM functions (s ee e.g. $[2,8,9,12,22]$ ) a re not included in this article, because the approaches used are multiple and thus the function represented are a lways a consequence of the dominant mind setting. Therefore we outlined a theoretical fra mework for func tions of TM especially for an industrial organisation (Fig. 1). This framework is a synthesis of our theoretical study and explains how the technology management functions are understood in this study.

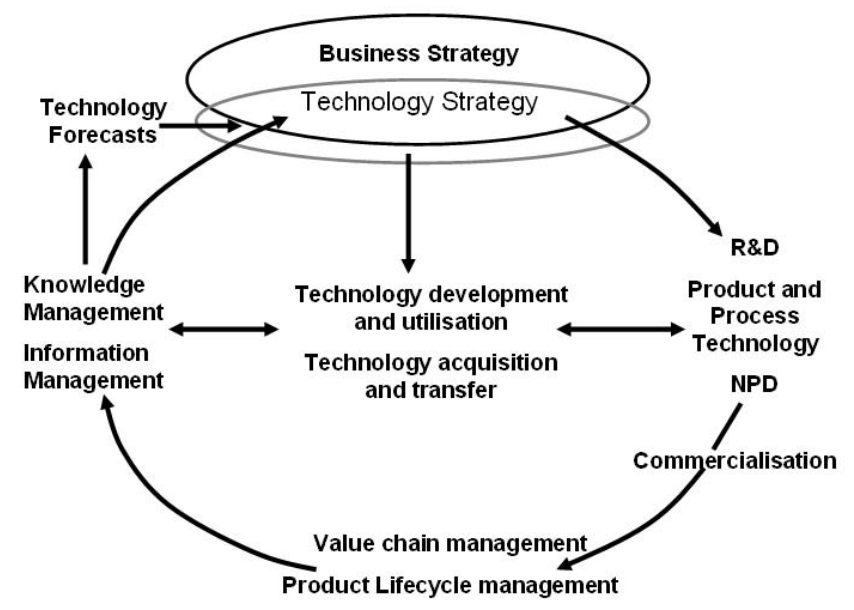

Fig. (1). The managerial functions of TM from the view point of the industrial company.

Technology Management involves management of all the key fa ctors of produc tion $\mathrm{t} o$ create we alth. $\mathrm{T}$ he main branches are $r$ esearch, $d$ evelopment, $p$ lanning, en gineering, machines, s oftware, produc tion, a nd communication. T he goal of te chnology management is to make everything work together in the most ef ficient $\mathrm{w}$ ay to p roduce profit for the company in the long-term. In this respect, the emphasis is on the word 'long-term'. The goal of big profits cannot be pursued wi thout a fut ure. S ometimes, $m$ anaging for $t$ he $s$ hort term is necessary, but to secure continuity of the company the long-term aspect is essential. For this reason, all the decisions must lie on a sound base and good business ethics, and ongoing organisational development must be planned. Accurately ha ndled $\mathrm{m}$ anagement $\mathrm{c}$ an $\mathrm{c}$ reate a huge a dvantage against competitors, $\mathrm{w}$ hereas inadequate $\mathrm{m}$ anagement $\mathrm{c}$ an damage a whol e company. There is no $b$ enefit from goo $d$ employees if the management cannot use them. Furthermore, managing a company is not always the same, it is dynamic in nature. It is not possible to just copy the management style from a s uccessful company because there are no two identical companies. In addition, the culture of the firm affects the management style too (see e.g. [23-26]).

To be as successful as planned, it is important to identify what to produce and how and have answers to the following issues: why to be in the business, what customers' problems can be solved, both from a technology point of vi ew, and from an engineering point of vi ew. In ot her words: a company ne eds a s trategy. The s trategy de fines the company's future. In simple terms, a strategy can be said to consist of a mission and a vision. The mission defines what the company will do, and the vision defines where it is aiming. However, it is not enough to establish a fancy strategy, it has to be executed.

A strategy cannot be just decided at the board of directors. It $\mathrm{n}$ eeds information to support its guidelines. For that purpose the bus iness e nvironment $\mathrm{m}$ ust be studied a nd a 
forecast made for the industry and its products. It should be noted that the industry, where the company acts, influences the competitive rules of the business as well as the strategies exploitable in a company [27].

For a company to make the right decisions related to its technology strategy, it needs reliable evaluations of the possible direction of the technology. This means close interaction between the industry and other relevant parties like universities and independent $r$ esearch unit $s$. It is ne cessary to study how the competitors are acting and how the technology will evolve in the future. In th is study, the issue of the community fore casting on te chnology is outs ide the s cope and c oncentrates on c ompany level fore casting a ctivities which a re unde rstood as a way of $\mathrm{c}$ reating information for the purpose of T M and strategic management [28]. Equally with the technology forecasting, it is important to know what the customers need and how to serve them best. It is necessary to know the customers' needs better than they do themselves. That knowle dge $\mathrm{c}$ reates $\mathrm{c}$ ompetitive a dvantage. Moreover, the company must know what is its' most valuable c apability, co re co mpetency. A ccording to Tee ce [27], the w inning companies in hi gh technology i ndustries ha ve rapid and flexible product innovation together with the management capability to ef fectively coordinate an $\mathrm{d} r$ edeploy internal and external competencies.

When th e s trategy is $d$ efined it $g$ ives d irection to th $\mathrm{e}$ whole co mpany. The co mpany s tarts to concentrate to p roduce its products leaning on its strengths. Needed technology is either produced in the company, or acquired or transferred into the company. $T$ he $s$ trategy gi ves di rection to the de partments and defines how to execute it.

In the end, the management's purpose is to support the strategy. They have to ensure that the right steps a re taken and things are done right. Success depends on the company's two key ingredients - technical resources and the capabilities to manage those [5]. Managers have to create a good targetoriented a tmosphere, a nd $\mathrm{m}$ ake $\mathrm{s}$ ure that a $11 \mathrm{t}$ he ne cessary material is available for de veloping the individuals and the organisation. The orga nisation $\mathrm{m}$ ust e volve all the time to remain co mpetitive in a tu rbulent $b$ usiness en vironment. Controlling re sources and risk management $\mathrm{c}$ an ensure that random backlashes do not jeopardise the company's future.

Information management is one important part of $m$ anagement. Without a fast and functional information system, projects fail and delays or even cancellations reduce a company's profit and re putation as a reliable manufacturer, cooperator or s upplier. The companies de velop their information s ystems a ll the time - howe ver whe $\mathrm{n}$ orga nisations make im provements in the a rea of i nformation and knowledge management, they often make it only for explicit knowledge. However, they should notice that it is tacit knowledge which gi ves s trategic advantage [29]. Tacit knowle dge is more complex to understand and handle. Companies require solutions for $\mathrm{t}$ acit knowle dge $\mathrm{m}$ anagement be cause $\mathrm{h}$ ighly tacit knowle dge indicates that the underlying structures are not well understood. An orga nisation c annot improve those aspects which it does not understand [27].

As presented in Fig. (1), strategy is affected by fore casts and th e co mpany's co re co mpetence. $\mathrm{O} n$th e o ther $\mathrm{h}$ and strategy a ffects technology development, a cquisition, trans- fer, i nnovation a nd R\&D. T hrough these ope rations input comes for new product development. $\mathrm{R} \& \mathrm{D}$ is a separate part from ne $\mathrm{w}$ produc $\mathrm{t} d$ evelopment, and re fers $\mathrm{m}$ ore $\mathrm{t} \mathrm{o} \mathrm{b}$ asic research and advanced research to find new technologies, not to engineer products.

\section{METHODOLOGY}

The empirical s tudy wa $\mathrm{sc}$ onducted to obta in an understanding of the current state of TM in Finnish high tech companies. The number of $F$ innish high tech oriented companies is extensive, but $m$ any of these companies are micro companies and thus not re levant for this study. For that reason, we selected the companies which represent average Finnish high tech oriented companies. The co mpanies were selected because of their clear high technology orientation, and thus have an interest in technology management issues.

Because of the limited resources, but in compliance with the requirements of qualitative research, the selected companies have to be easily and reliably av ailable. In to tal, 19 responses were received from the industry representatives via interviews or que stionnaire (Table 1). None of the contacted persons re fused an interview. The amount of re sponses is considered to b e sufficient for th is $r$ esearch purpose to in crease understanding of the studied field. The sample can be seen to be re presentative as, during the last interviews, we did not find any new and different information.

Table 1. Background Information of the Respondents

\begin{tabular}{|c|c|c|}
\hline & $\begin{array}{c}\text { Amount of } \\
\text { Companies }\end{array}$ & $\begin{array}{c}\text { Amount of } \\
\text { Responses }\end{array}$ \\
\hline \hline Large companies (over 400 employees) & 7 & 11 \\
\hline Small companies (below 400 employees) & 8 & 8 \\
\hline In total & 15 & 19 \\
\hline
\end{tabular}

Overall, the research was carried out in 15 companies. 7 of these companies are classified as large companies, and 8 represent $\mathrm{s}$ mall co mpanies. $\mathrm{O} f$ th e larger co mpanies, more than 1 participant was usually interviewed to triangulate the answers, but a lso $t o$ ga in i nformation from the di fferent business units.

The interviewed participants were chosen on the basis of their profe ssional background and expertise. The interviewees hold re sponsible pos itions in m anagement a ctivities re lated to te chnology and thus have up-to-date knowle dge of the discussed topics. The job titles of the respondents include the fol lowing: the CEO, C TO, De velopment Ma nager, Director of R\&D, P roduct De velopment Manager, S enior D irector of Competence Centre, Director of Product and Technology Management, Head of T echnology and Architecture Management, D irector of Rich Int ernet S ervices, Engineering and Site Manager, and the Head of Division.

The study was carried out in spring 2008 us ing the normative research approach to improve existing knowledge of technology management. The research process started studying the fie ld of T M. The que stionnaire us ed $\mathrm{w}$ as structural and contained qualitative and quantitative parts. The qualita- 
tive que stions w ere us ed to identify what e ach func tion of TM means to the companies - how they describe the content of each area of TM and what are the practical implications in the specific function of TM. The quantitative part focuses on identifying the importance of e ach subfield of TM and what is the current state of operation. The evaluation scale used in this part was the Likert-scale 1-10, where number one is "not important" (measure of importance) or "not practised" (current s tate m easurement), and number ten is "extremely important" or "a well established practice".

In the questionnaire we briefly defined all the TM functions presented in the theoretical framework ( see Fig. 1), in order to obtain valid information from the respondents. This was done because T M consists of $\mathrm{m}$ any different functions which are somehow related to each other. These descriptions are presented in Table 2.

\section{RESULTS}

The r esearch is qualitative but in cludes some numerical data. The qua litative $r$ esearch methods a nd $r$ equirements guide this study. The qualitative part illustrates the common perception of T M in the case companies, but also an alyses the di fferences be tween the c ompanies, a nd pos sible root causes of these differences. The quantitative part of the study concentrates on determining the importance and current state of certain functions of TM in the case companies.

\section{The Perception of Te chnology Man agement in $F$ innish High Tech Companies}

The summary of the results from the qualitative questions about the c ontent of $\mathrm{c}$ ertain func tions of $\mathrm{t}$ echnology $\mathrm{m}$ anagement is presented in Tables 3 and 4 . The covered functions of TM were strategy related as in Matthews' [18] ap proach in grouping R\& D pro jects which links the s trategy and produc $t$ de velopment a spects, technology de velopment and ut ilisation, i nformation a nd knowl edge $\mathrm{m}$ anagement, technology a cquisition and transfer, te chnology fore casting, product development and innovation actions outside product development, life cycle management, and production process management.

Table 2. Operationalised Definitions of the TM Functions of this Study

\begin{tabular}{|c|c|}
\hline $\begin{array}{l}\text { Technology Management } \\
\text { Function }\end{array}$ & Definition of TM Function \\
\hline Technology strategy & $\begin{array}{l}\text { Technology strategy consists of the definition, development and use of those technological competencies that constitute the } \\
\text { company's competitive advantage [12]. To define the technology strategy, organisational context, environmental context, and } \\
\text { technology evolution are assessed according to the strategic decisions (e.g. make or buy, licensing in/out etc.) [2,9]. The tech- } \\
\text { nology strategy is the basis for the business strategy }[9,12] \text {. }\end{array}$ \\
\hline $\begin{array}{l}\text { Technology development } \\
\text { and utilisation }\end{array}$ & $\begin{array}{l}\text { Technology development consists of basic and applied research, practical solution development, and technology enhancement } \\
\text { [22]. Technologies are utilised during product development, but on a wider scale than a single product or product family. } \\
\text { Technologies can be also patented and offer intellectual property rights (IPR) for sale. Technology utilisation contains also the } \\
\text { elements of technology infrastructure. }\end{array}$ \\
\hline $\begin{array}{l}\text { Information and } \\
\text { knowledge management }\end{array}$ & $\begin{array}{l}\text { Knowledge management contains both tacit and explicit knowledge [30]. "Knowledge is the "key to control" over technology } \\
\text { as a whole" [1]. Information is processed data whereas knowledge is context-related. }\end{array}$ \\
\hline $\begin{array}{l}\text { Technology acquisition } \\
\text { and transfer }\end{array}$ & $\begin{array}{l}\text { Technology transfer is the movement of technological capability (artefacts, information, rights, and services) [12], within a } \\
\text { company or from a company to another company. The ways of technology acquisition are multiple. It can take the form of } \\
\text { internal R\&D, joint venturing, contracting out for R\&D, licensing in, and buying technology [22]. }\end{array}$ \\
\hline Technology forecasting & $\begin{array}{l}\text { Forecasting is predicting future technologies and assessing an organisation's capability to handle them [8] and thus decrease } \\
\text { the level of uncertainty. Forecasting includes continuous monitoring of technological developments leading to an early identi- } \\
\text { fication of promising future technology fields and validation of their potentials. Technology foresight is a tool assisting deci- } \\
\text { sion makers to optimise the decisions of R\&D at a strategic level }[31,28] \text {. }\end{array}$ \\
\hline Product development & $\begin{array}{l}\text { R\&D refers to the generation of basic research (for example technology development) and new ideas. Companies should have } \\
\text { different types of R\&D projects to ensure profits over a long period (see e.g. [18]). Product development aims to create a } \\
\text { saleable product (physical product, software, service etc.) (see e.g. [32-35]) but also to develop product technologies. }\end{array}$ \\
\hline Life cycle management & $\begin{array}{l}\text { Technology life cycle consists of embryonic, growth, and maturity phases. "Most technologies will be replaced and most } \\
\text { efforts to replace them will fail", [18]. When the natural limits of technology have been reached, the technology has become } \\
\text { vulnerable to substitution or obsolescence. Discontinued technologies replace obsolete products on the market and developing } \\
\text { old technology is no longer worth it }[2,22] \text {. }\end{array}$ \\
\hline Commercialisation & $\begin{array}{l}\text { Commercialisation involves delivering products from development to the market, and thus is not only a synonym of launch- } \\
\text { ing. Technology commercialisation includes finding applications for immature technologies, and captures the iterative nature } \\
\text { of such efforts [36]. Commercialisation means also technological commercialisation including the aspects of IPR and licens- } \\
\text { ing activities, for example [12]. }\end{array}$ \\
\hline $\begin{array}{l}\text { Production process } \\
\text { management }\end{array}$ & $\begin{array}{l}\text { Selection of the inputs, operations and methods (process technologies) that transform the inputs to desired outputs [37]. A } \\
\text { production system creates deliverables as defined in product development. }\end{array}$ \\
\hline
\end{tabular}


In Tables $\mathbf{3}$ and $\mathbf{4}$, the practices of TM are summarised. On the T M function level, there ar e similarities w ithin the case companies, although differences between the companies are visible too (Tables $\mathbf{3}$ and $\mathbf{4}$, third column). The company size seems to play an important role in the differences which arise about how a particular company addresses te chnology management.

In a ddition to company size, the $\mathrm{n}$ ature of $\mathrm{t}$ he bus iness causes differences between companies depending on whether the company is an ICT company or not. F or ex ample, the business $\mathrm{c}$ lock speed is a ffected in the range of $t$ echnology planning period, i.e. in ICT companies the planning period is shorter than in the o ther case high tech (non-ICT) co mpanies.

\section{Evaluating the Importance of TM Functions}

Tab le 5 p resents the quantitative results of the research. The importance of a certain func tion of $\mathrm{T} \mathrm{M}$ and $\mathrm{c}$ urrent status is evaluated using a range from 1 to 10 . Even though the scale used is ordinal, the mean value is used in the analysis, as is often us ed in this kind of re search. By us ing the mean value, we a re simplifying the re sults and thus losing part of the statistical information. However, it is not the aim to be very specific in this respect, when the main objective of the re search is to identify the $m$ ain $s$ treams of te chnology management func tions so as to ga in a better understanding about the current situation of te chnology $m$ anagement in Finnish $\mathrm{h}$ igh $\mathrm{t}$ ech co mpanies. The $\mathrm{m}$ ean $\mathrm{v}$ alue tells more about the relative order of the evaluated TM functions and is the basis for the gap analysis presented later.

In summary, none of the functions is ranked as extremely important or not im portant a $t$ all. A ll of $t$ he func tions, e $x-$ cluding t echnology commercialisation, a re evaluated between 7.1 to 8.6 and thus prove that most of the operations of $\mathrm{TM}$ are important and there is not just one most important area. Howe ver, it $\mathrm{s}$ hould be not ed that $\mathrm{w}$ e ha ve a lready

Table 3. Description of Technology Management Functions in Finnish High Tech Companies (Part 1)

\begin{tabular}{|c|c|c|}
\hline $\begin{array}{c}\text { Technology } \\
\text { strategy }\end{array}$ & $\begin{array}{l}85 \% \text { of the companies have a technology strategy and about } 70 \% \\
\text { can clearly define it. In most of the cases the strategy is strongly } \\
\text { based on the customers needs and it is mostly executed as part of } \\
\text { the annual planning process. } \\
60 \% \text { clearly stated that the business and technology strategies go } \\
\text { hand in hand and the technology strategy supports the whole busi- } \\
\text { ness strategy and its needs. }\end{array}$ & $\begin{array}{l}2 \text { companies reported being a subcontractor so they are fulfilling } \\
\text { customers' needs and thus do not need their own technology strat- } \\
\text { egy. And in } 2 \text { other companies the meaning of technology strategy } \\
\text { seems to be a little different to that understood in this study gener- } \\
\text { ally. }\end{array}$ \\
\hline $\begin{array}{c}\text { Technology } \\
\text { development and } \\
\text { utilisation }\end{array}$ & $\begin{array}{l}47 \% \text { of the organisations, which develop technology, has a clear } \\
\text { formula for technology development. These companies generally } \\
\text { do not sell developed technologies, at least not systematically. } \\
\text { Almost } 80 \% \text { of the respondents reported having co-operation with } \\
\text { other companies. Especially all the small firms co-operate as a way } \\
\text { to get competence, technology, and special skills. }\end{array}$ & $\begin{array}{l}\text { Only } 1 \text { response showed that one organisation does not have a clear } \\
\text { formula for technology development, even though they are devel- } \\
\text { oping technologies. } \\
\text { Non-ICT firms are doing much less co-operation with other com- } \\
\text { panies than ICT firms. }\end{array}$ \\
\hline
\end{tabular}


Table 4. Description of Technology Management Functions in Finnish High Tech Companies (Part 2)

\begin{tabular}{|c|c|c|}
\hline $\begin{array}{l}\text { Technology } \\
\text { forecasting }\end{array}$ & $\begin{array}{l}\text { About } 60 \% \text { of the interviewees regard technology forecasting } \\
\text { as a systematic operation in their organisation. } \\
\text { Almost all the companies use some kind of competitor analysis } \\
\text { in their forecasting activity. }\end{array}$ & $\begin{array}{l}\text { The methods and approaches to forecasting are varied. The most } \\
\text { mentioned were the conversations with the vendors, customers } \\
\text { and partners. Others are more company specific tools: collabora- } \\
\text { tion with universities and independent research centres, publica- } \\
\text { tions, consultants, observing trends and patents, analyst sessions. } \\
\text { Some of the firms divided technology into smaller parts to facili- } \\
\text { tate observation, and roadmap techniques were used too. }\end{array}$ \\
\hline Product development & $\begin{array}{l}\text { Excluding the big ICT companies, which invest a lot in product } \\
\text { development, there is no common picture about the amount of } \\
\text { investment in product development. } \\
\text { Parallel technology development is not used: companies do not } \\
\text { have resources for it and thus it is thought to be impossible } \\
\text { especially in the small companies. } \\
87 \% \text { of all the companies use platforms in their product devel- } \\
\text { opment. The small companies regard the platforms as being } \\
\text { very important. } \\
68 \% \text { of all the companies use the Matthews' "blue box" } \\
\text { (grouping R\&D projects) model and which describes ICT com- } \\
\text { panies approach to R\&D and product development activities. } \\
\text { However, in the ICT companies, the time scale of the } \\
\text { Mathews' original "Blue Box"-approach was clearly too long. } \\
40 \% \text { of all interviewees said that the time scale is shorter than } \\
\text { in the Matthew's model. } \\
\text { Twofold results on innovation activities: the big companies } \\
\text { have at least some kind of innovation activities outside product } \\
\text { development but none of the small companies have innovation } \\
\text { actions separate from the product development. }\end{array}$ & $\begin{array}{l}\text { Some of the case companies understood that they do only product } \\
\text { development, so all the investment goes into product develop- } \\
\text { ment. Non-ICT, large companies do not invest much, compared } \\
\text { with their turnover, in product development. } \\
3 \text { of the companies reported that they use parallel development in } \\
\text { small details inside technologies etc. } \\
\text { Only } 2 \text { of the companies did not use platforms at all and the main } \\
\text { reasons were because of the nature of the industry where they } \\
\text { operated. } \\
\text { Big differences appear between the big and small companies: } 10 \\
\text { of } 11 \text { big company representatives said that the Matthews' "blue } \\
\text { box" (grouping R\&D projects) model is used, but only } 3 \text { of } 8 \\
\text { small companies said this kind of model is used. Clearly the non- } \\
\text { ICT respondents were more familiar with the approach than the } \\
\text { respondents the ICT firms. } \\
\text { Innovation outside product development did not seem to be very } \\
\text { systematic, but there were some exceptions for example a com- } \\
\text { pany having extensive innovation council etc. }\end{array}$ \\
\hline Commercialisation & $\begin{array}{l}\text { Commercialisation was much more important for the small } \\
\text { companies, but it was regarded as the least important field by } \\
\text { both groups. } \\
\text { Interviewees in the big companies were thinking commerciali- } \\
\text { sation as the way to make profit from the know-how. }\end{array}$ & $\begin{array}{l}\text { The understanding of commercialisation was fragmented. Also } \\
\text { the importance and current state in both groups varied greatly. } \\
\text { Partly this can be explained by the different interpretations of } \\
\text { what commercialisation means. } \\
\text { Technology commercialisation was regarded in small firms in } \\
\text { two ways: (1) some of the respondents of the small firms thought } \\
\text { it meant selling their own product, and (2) some thought it could } \\
\text { be selling and licensing self developed architecture and patents. }\end{array}$ \\
\hline $\begin{array}{l}\text { Production process } \\
\text { management }\end{array}$ & $\begin{array}{l}\text { Production technology was seen mostly as machinery and } \\
\text { methods for producing products. It is important to keep the } \\
\text { costs of big volume production down and stay competitive. } \\
\text { One respondent included a whole delivery chain under produc- } \\
\text { tion technology. } \\
\text { Lifecycle planning should take into account the whole chain } \\
\text { from raw materials to cast-off products. }\end{array}$ & $\begin{array}{l}\text { The respondents of the small companies regarded production } \\
\text { technology as the control of a production process and techniques. } \\
\text { It includes also tools used to make and maintain products. In } \\
\text { addition, the type of product affects the production technology. }\end{array}$ \\
\hline
\end{tabular}


selected the most important functions from the literature review for the evaluation, and thus the importance of a 11 the functions of TM presented in this study is already assumed.

Deviation among the respondents is not high and mostly less than 2 units. The definitions of certain functions by the interviewees explain s ome of the d eviations. For e xample, production process management and its sub-part, production technology, a re va riously unde rstood $-\mathrm{s}$ ome i nterviewees are closely bound to the production process and methods, or even to the whole delivery chain, when some others regard interconnections between a product and production technology s o that $t$ he produc $t$ a ffects $t$ o produ ction $t$ echnology. Deviation in the concept of $t$ echnology strategy arises from the industry where the company operates - non-ICT companies a nd a lso the s ubcontractors do not re gard t echnology strategy as important at all, which appears also in the results presented in Tables 3 and $\mathbf{4}$.

Table 5. Importance and $C$ urrent $S$ tatus of the $F$ unctions of TM in Finnish High Tech Companies

\begin{tabular}{|c|c|c|}
\hline Function of TM & $\begin{array}{c}\text { Importance } \\
(\mathbf{1 - 1 0})\end{array}$ & $\begin{array}{c}\text { Current Status } \\
\mathbf{( 1 - 1 0 )}\end{array}$ \\
\hline \hline Technology Strategy & 7,7 & 6,7 \\
\hline Technology Development & 8,3 & 7,0 \\
\hline Technology Utilisation & 8,06 &, 9 \\
\hline Information and Knowledge Management & 8,27, & 4 \\
\hline Technology Acquisition & 7,77, & 4 \\
\hline Technology Transfer & 7,1 & 6,5 \\
\hline Technology Forecasting & 7,8 & 6,9 \\
\hline Product Development & 8,6 & 7,1 \\
\hline Life cycle Management & 8,2 & 6,8 \\
\hline Commercialisation & 6,45, & 3 \\
\hline Production Process Management & 8,1 & 6,8 \\
\hline
\end{tabular}

According to the results, the most important functions of technology management va ry be tween the large and s mall companies (Table 6). In the list of $t$ op five of the most important func tions of $\mathrm{T} \mathrm{M}$, the s ame three func tions $\mathrm{c}$ an be found, regardless of the group of respondents. Both small and $l$ arge companies va lue produc $t d$ evelopment $h$ igh and, therefore, product development is number one on the lists of all the respondents. The second important function, on all the companies' lists, is technology development, and the third is information and knowledge management.

The commercialisation of technology is evaluated as the least significant within small and large companies. It is also interesting to note that the commercialisation is $\mathrm{much}$ le ss valued by the large companies than the small companies. In addition, the current status of technology commercialisation is r egarded a s most critical (i.e. the lowest $r$ ate). These results a re quit e $\mathrm{c}$ ontradictory $\mathrm{s}$ ince the re spondents $\mathrm{r}$ egard commercialisation a s the method by whi ch to ga in profi ts from the knowledge.

The gaps between the importance of certain functions of $\mathrm{TM}$ and the current status are not very deep overall (see Fig. 2). Howe ver, c ertain di fferences be tween la rge a nd s mall companies are v isible ( see T able 7). S mall c ompanies c onsider that their biggest gaps are in: technology commercialisation, technology development, and product development even when they are engineering technology oriented org anisations.

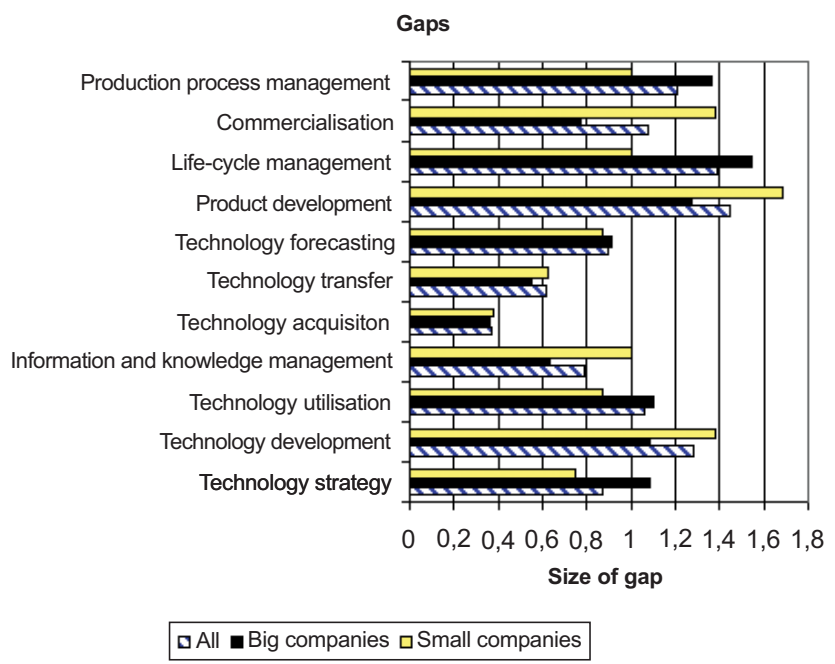

Fig. (2). The gaps between the importance and current status of TM functions in Finnish high tech companies.

Table 6. Most Important Functions of TM Wide

\begin{tabular}{|c|c|c|c|}
\hline Priority & All Respondents & Large Companies & Small Companies \\
\hline \hline $1 \mathrm{P}$ & roduct development & $\begin{array}{c}\text { Product development \& } \\
\text { Production process management }\end{array}$ & Technology development \\
\hline 2 & Technology development & Product development \\
\hline 3 & Information \& knowledge management & Technology utilisation \\
\hline 4 & Life cycle management & Information \& knowledge management & Information \& knowledge management \\
\hline 5 & Production process management & Technology development & Life cycle management \\
\hline
\end{tabular}


Table 7. The Biggest and Smallest Gaps Between the Importance and Current Status from the Group of Respondents

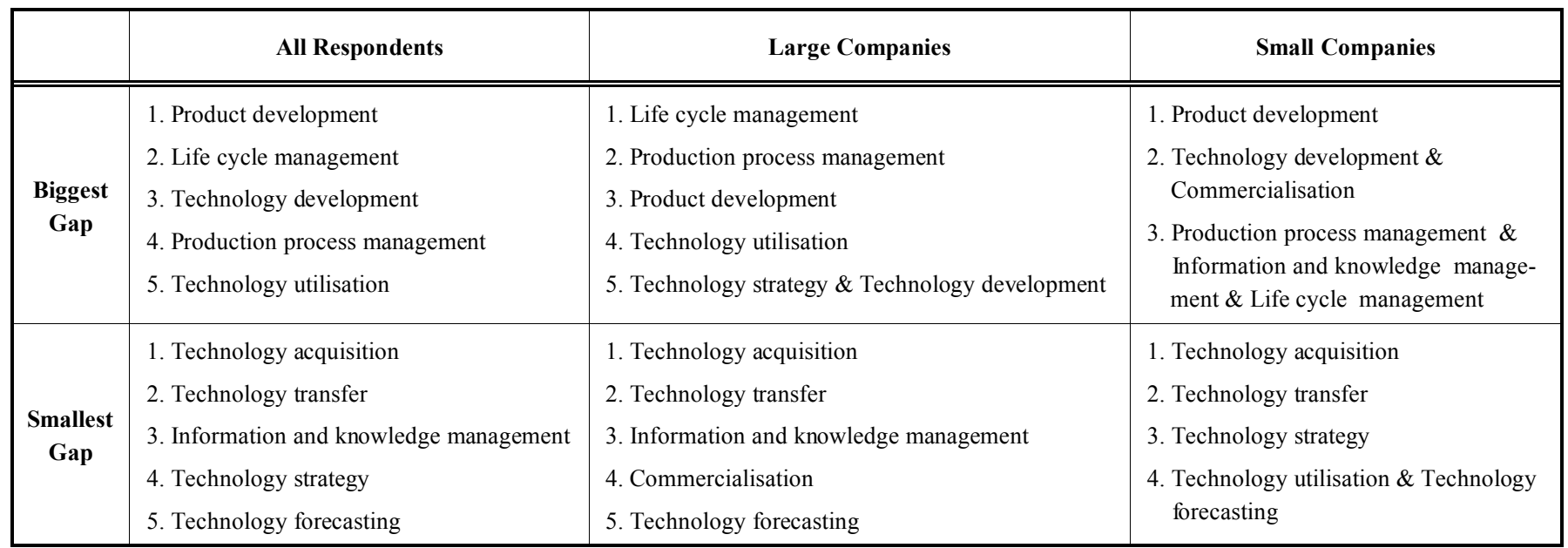

Among the la rger companies, the different func tions of TM are regarded as follows: life cycle management, production process management as well as product development are the most challenging operations followed by technology development, te chnology s trategy a nd t echnology ut ilisation, which a re re garded a be ing e specially re lated to the te chnology infrastructure.

Technology t ransfer a nd a cquisition func tions we re re garded a s be ing managed quite we $11 \mathrm{in}$ all the companies. Acquiring technologies was not considered a problem as the results show, and technology transfer is in good shape.

\section{DISCUSSION}

When e valuating the i mportance of di fferent $\mathrm{T} M$ func tions, it became clear that some functions are not so relevant in cer tain ty pes of companies. For ex ample, software developers do not value production process management and especially production te chnology, or technology de velopment because $m$ ost $o f$ th ese co mpanies ar e $n$ ot d eveloping th $e$ technology utilised. Furthermore, the software developers do not regard their operative process as "software production". From a bus iness $m$ anagement point of vi ew, this is ra ther strange, because this process "should" be operative as a "order-delivery proc ess" from the orga nisation point of vi ew. Also the im portance of $t$ he $t$ echnology s trategy a nd e specially the strategy time span relates to the industry in which the company operates, and thus a common and general perception of TM is elusive.

The $\mathrm{m}$ ost va lued func tions of $\mathrm{T} \mathrm{M}$ in $\mathrm{t}$ he $\mathrm{c}$ ase $\mathrm{F}$ innish high tech companies were product development, technology development, and technology utilisation. Al so the li fecycle approach and produc tion proc ess $m$ anagement a re a mongst the most highly valued. However, small and large companies have di fferent challenges, whic $h \mathrm{c}$ an be $\mathrm{s}$ een in the ga $\mathrm{p}$ analysis.

The i mportance of $t$ echnology de velopment is conflicts with the fact that a lmost half of the case companies do not develop te chnology themselves and the technology a cquisition is experienced as being well managed. One explanation might be that they just do not understand the difference be- tween order-delivery and product creation process from the organisational perspective.

The produc $\mathrm{t}$ and e ngineering re lated $\mathrm{T} \mathrm{M}$ func tions a re highlighted. Finnish companies have a very strong engineering background [6] whi ch can be seen also in these results. Product de velopment and produc tion proc ess m anagement, developing technology, the e ngineering-linked li fecycle aspect together with technology utilisation and information and knowledge $\mathrm{m}$ anagement a re the most $\mathrm{h}$ ighly va lued func tions of TM. The view of technology utilisation and information management is very application-related.

The reasons for such a low valuation of technology strategy by the cas e companies might be because of, es pecially, the experiences of small firms. They feel they are not able to make no table de cisions themselves concerning te chnology choices. M ost of the te chnological c hoices come from the bigger players, and the small firms merely have to follow the given directions. This does reflect on, and influence, not only the technology strategy decisions but the forecasting as well. When the guidelines a re set by the bigger players, it is not seen as important for the s maller players to forecast the future. How ever, every c ompany ne eds to unde rstand that changes in te chnologies $\mathrm{c}$ reate $\mathrm{n}$ ew bus iness opport unities [3] a nd thus companies ne ed to have s ome $\mathrm{k}$ ind of vi sion about the evolving te chnologies to compete also in the future. One possibility is to co-operate in networks and therefore have a better vision of future technologies.

The c ommercialisation of $t$ echnologies is ge nerally re garded as difficult and most new technology based business ideas will fail in the market [37], because they are there to o early and do not ful fil customers' n eeds but m erely s atisfy engineering de sires. $\mathrm{F}$ innish companies do $\mathrm{h}$ ave a s trong engineering a nd t echnical dri ve whe $\mathrm{n}$ de veloping produc ts and this study confirms the fact that Finnish companies' understanding of $\mathrm{t}$ he $\mathrm{c}$ ommercialisation of technology is not fully internalised.

In this study, the interviewees were all working in positions where management decisions regarding technology are made. Howe ver, technology $m$ anagement nowa days re lates to general managerial tasks and should not be taken in one 
specific de partment a nd $t$ hus $t$ he $s$ ame ki nd of $s$ tudy is needed in o ther co mpanies to as sess the importance of the technology management s egment from a bus iness management point of view. Moreover, the number of interviews per company should be higher to understand the company as a whole not just via one or a few persons.

\section{CONCLUSIONS}

The area of TM is very wide and offers multiple theoretical frames to practitioners. This study shows that none of the TM functions is more important than another when managing technology. One reflection on RQ1 (see Fig. 1, Table 2) should be that the frame is not the purpose in itself, it is more relevant to understand the context in managing technology. Furthermore the co ntent an d es pecially th e em phasis of a certain function of TM are company related. There was a gap of $2 \mathrm{u}$ nits be tween the values of $t$ he functions identified as the $\mathrm{m}$ ost and the least i mportant func tion of $\mathrm{T} \mathrm{M}$. T his t $\mathrm{o}-$ gether with some significant deviations among the responses related to s ome of $\mathrm{t}$ he studied functions confirms the findings in the literature that the importance of certain functions depends on the company's bus iness model, and all the TM functions a re not a s i mportant to e ach company. None theless, some common characteristics can be determined about how Finnish high tech companies understand TM functions.

Almost al 1 th e $\mathrm{c}$ ase co mpanies $\mathrm{h}$ ave a c learly $\mathrm{d}$ efined technology s trategy whi ch is integrated wit $\mathrm{h} t$ he bus iness strategy. The s trategic $p$ lanning pe riod is a t le ast in ICT companies $s$ horter th an th at $\mathrm{p}$ resented for ex ample in Matthews' theories. $60 \%$ of the studied co mpanies make technology forecasts, and almost all the companies use competitor analysis as one m ethod. Otherwise the technology forecasting methods are quite varied.

Technology acquisition does not appear to be a problematic area for $\mathrm{F}$ innish companies. Licensing or buying necessary technologies are commonly used methods. Furthermore, co-operation with o ther companies and r esearch centres are well used ways of de veloping technology and related skills. Almost all the companies utilise platforms in their product development, but companies do not have resources for parallel product development activities in principal.

The re sults on te chnology de velopment s how that onl y half of the studied high tech companies are actually developing technology themselves. Product de velopment, therefore, is based heavily on the other companies' technological solutions, $w$ hile the companies co ncentrate $\mathrm{m}$ ore o $\mathrm{n} s$ pecific product creation.

The cu rrent s tatus of $\mathrm{T} \mathrm{M}$ functions is on av erage quite high when compared to the current status of the experienced importance of certain functions. How ever, there are significant $d$ ifferences $b$ etween the $s$ mall and 1 arge co mpanies' current $\mathrm{s}$ tatus e valuations, and thus it can be $\mathrm{s}$ aid that the current status and the challenges depend largely on the company, its size, business model and maturity even for companies operating in the same industry. The differences $c$ an be linked also to the role of a company in an industry sector the position in a product value chain is a decisive factor for how the companies organise their TM functions.

In response to RQ2, product and technology development are $r$ anked as the most important $\mathrm{T} \mathrm{M}$ functions in $\mathrm{F}$ innish high $t$ echnology c ompanies. I $\mathrm{s}$ eems these ope rations a re vitally important in $\mathrm{TM}$, and one explanation of this can be the re spondents' te chnology orientated way of thinking and also the fact that at the core of Finnish high tech companies is a product, more than technology. This could partially explain why $\mathrm{F}$ innish firms have traditionally had s ome problems entering global markets: the produc ts may have be en superior but there has be en a la ck of $\mathrm{c}$ ommunication with potential customers wh ile de veloping the produc ts and a lso the unde rstanding of $t$ he customer ne eds might be i nadequate. Based on that, it is interesting to note that the technical pe ople do not $v$ alue the commercialisation ve ry $h$ ighly even though it is regarded as the way to make profit.

Commercialisation $\mathrm{w}$ as clearly s een a s the 1 east important function of TM in this study. It can be explained, at least partially, by the respondents' te chnology orientation, where product de velopment is s een pure ly a s a te chnical a ction without $\mathrm{c}$ onnection $\mathrm{t} \mathrm{o}$ marketing. Howe ver, the $\mathrm{f}$ indings from the literature indicate that commercialisation should be an integral part of the new product development. Therefore, linking $\mathrm{c}$ ommercialisation $\mathrm{t}$ o ne $\mathrm{w}$ produc $\mathrm{t}$ de velopment should be given more attention.

The purpose of this study was to obtain an understanding of the concept of technology management in F innish high tech co mpanies and analyse the cu rrent s tatus of T M. The studied area is very wide and during the research it became clear that the terms and concepts were variously understood. This raised a challenge for the analysis. This study was not intended to be all-inclusive, but $r$ ather to create $a b$ etter understanding of $t$ he $c$ urrent $s$ tatus of $\mathrm{T} \mathrm{M}$ in practice. A s the sample was small, a wider set of interviews might have provided a somewhat different view.

\section{REFERENCES}

[1] Li-Hua R, K halil T. Technology m anagement in C hina: a g lobal perspective and challenging issues. J Technol Manage China 2006; 1(1): 9-26.

[2] Schilling MA. Strategic Management of Technological Innovation, $2^{\text {nd }}$ ed. New York: McGraw \& Hill 2008.

[3] Mogee M E. Ed ucating In novation M anagers: $S$ trategic Is sues fo Business an d H igher E ducation. I EEE T rans Eng M anage 1993; 40(4): 410-7.

[4] Xu Q, Chen J, Guo B. Perspective of technological innovation and technology management in China. IEEE Trans Eng Manage 1998; 45(4): $381-7$.

[5] Tidd J , B essant J , P avitt K . M anaging I nnovation: I ntegrating Technological, $\mathrm{M}$ arket and $\mathrm{O}$ rganizational $\mathrm{C}$ hange. $\mathrm{C}$ hichester, England: John Wiley \& Sons 1997.

[6] Silén T. La atujohtaminen - $\mathrm{m}$ enetelmiä $\mathrm{k}$ ilpailukyvyn $\mathrm{v}$ ahvistamiseksi, [in Finnish]. Porvoo, Finland: WSOY 1998.

[7] National R esearch C ouncil - N RC. Management of T echnology. The Hidden Competitive Advantage. Washington DC, U.S.A: National Science Foundation; February 1987.

[8] Steele LW. Managing Technology. The Strategic View. New York: McGraw-Hill 1989.

[9] Burgelman RA, M aidique M A, Wheelwright S C. S trategic M anagement of Technology and Innovation, $2^{\text {nd }}$ ed. USA: Times Mirror Higher Education Group Inc. 1996.

[10] Matthews WH. C onceptual framework for in tegrating te chnology into business strategy. Int J Veh Des 1992; 13(5/6): 524-32.

[11] Betz F. S trategic T echnology Management. N ew Y ork: McGrawHill, Engineering and Technology Management Series 1993.

[12] Dodgson M. T he M anagement of T echnological I nnovation. A n International a nd s trategic A pproach. $\mathrm{O}$ xford, $\mathrm{U}$ nited $\mathrm{K}$ ingdom: Oxford University Press 2000.

[13] Dussauge P, Hart S, R amanantsoa B. Strategic T echnology Management. $2^{\text {nd }}$ ed. Paris, France: John Wiley \& Sons 1992. 
[14] Pawitt K. What we know about the strategic management of technology. Calif Manage Rev 1990; 32(3): 17-26.

[15] Hamilton W F. M anaging t echnology as a s trategic as set. I nt J Technol Manage 1997; 14(2/3/4): 163-76.

[16] Bhalla S K. T he E ffective M anagement of T echnology: A C hallenge for Corporations. Columbus, Ohio: Battelle Press 1987.

[17] Mitchell GR, Hamilton WF. Managing R\&D as a Strategic Option. Res Technol Manage 1988; 15-22.

[18] Matthews WH. Kissing technological frogs: Managing technology as a strategic resource. Eur Manage J 1991; 9(2): 145-8.

[19] Dodgson M. The Management of Technological Learning. Lessons from a B iotechnology C ompany. B erlin - N ew Y ork: W alter de Gruyter 1991.

[20] Carayannis EG. Strategic Management of Technological Learning. Boca Raton, USA: CRC Press 2000.

[21] Talonen T. Developing Management of Technology Processes in a Global Technology Corporation. [Licentiate Thesis, Department of Industrial Engineering, University of Oulu] 2008.

[22] Khalil T. M anagement of Te chnology - The K ey to Competitiveness and Wealth Creation. Ney Jersey: Prentice Hall 2000.

[23] Christensen CM. The Innovator's Dilemma. When New Technologies $\mathrm{C}$ ause $\mathrm{G}$ reat $\mathrm{F}$ irms to $\mathrm{F}$ ail. $\mathrm{B}$ oston, $\mathrm{M}$ assachusetts: $\mathrm{H}$ arward Business School press 1997.

[24] Goldratt EM. What is th is th ing c alled th eory of $\mathrm{c}$ onstraints a nd how should it be implemented? New York: North River Press Inc. 1990.

[25] Moore G A. Inside the to rnado. Marketing s trategies from Silicon Valley's cutting edge. Oxford, United Kingdom: Capstone Publishing Limited 1998.

[26] Moore GA. Crossing the chasm. Marketing and selling technology products to mainstream customers. Oxford, United Kingdom: Capstone Publishing Limited 1999.
[27] Teece DJ, Pisano G, Shuen A. Dynamic capabilities and strategic management. Strategic Manage J 1997; 18 (7): 509-533.

[28] Porter AL, Roper AT, Mason TW, Rossini FA, Banks J. Forecasting and Management of Technology. New York, USA: John Wiley \& Sons 1991.

[29] Haapasalo H, K ess P. In S earch of organisational c reativity: th e role of knowledge management. C reativ Innov Manage 2001; 10 (2): $110-8$.

[30] Nonaka I, Takeuchi H. The Knowledge-Creating Company: How Japanese $\mathrm{C}$ ompanies $\mathrm{C}$ reate $\mathrm{t}$ he $\mathrm{D}$ ynamics of I nnovation. $\mathrm{N}$ ew York, USA: Oxford University Press 1995.

[31] Holtmannspötter D, Zweck A. Monitoring of Technology Forecasting A ctivities - A n ES TO P roject R eport [ Online]; 2001 [ cited 2008 February 2]. A vailable from:http://esto.jrc.es/docs/forecsting. pdf

[32] Urban GL, Ha user JR. De sign a nd M arketing of Ne w P roducts. Englewood Cliffs, New Jersey: Prentice Hall Inc. 1980.

[33] Ulrich KT, Eppinger SD. Product Design and Development. $2^{\text {nd }}$ ed. New York: Irwin McGraw-Hill 2000.

[34] Cooper R G. W inning at N ew Products: A ccelerating the P rocess from Idea to Launch. 3rd ed. Cambridge, Massachusetts: Perseus Publishing 2001.

[35] Jolly VK. Commercializing new technologies: getting from mind to market. Boston: Harvard Business School Press 1997.

[36] Krajewski L, R itzman L, Malhora M. O perations M anagement Processes and Value Chains. New Jersey, USA: Pearson Education Inc. 2007.

[37] Howard WG, Guile BR. Profiting from Innovation. New York: The Free Press 1992.

(C) Kropsu-Vehkapera et al.; Licensee Bentham Open.

This is an open access article lic ensed under the terms of the Creative Commons Attribution Non-Commercial Lic ense (http://creativecommons.org/licenses/ by-nc/3.0/) which permits unrestricted, non-commercial use, distribution and reproduction in any medium, provided the work is properly cited. 